\title{
First report of the phytoseiid mite Neoparaphytoseius charapa Jiménez, McMurtry \& Moraes, 2014 (Acari: Phytoseiidae) to Brazil, with notes on the occurrence of the genus
}

\author{
Raimundo B. Souza ${ }^{1 \oplus}$, Michele P. Duque $\left.{ }^{2(}\right)$, Suziane A. Amorim ${ }^{2 \oplus}$, Ana C. C. Cavalcante ${ }^{2 \oplus}$, \\ Isabel R. Guesdon ${ }^{2}$, Peterson R. Demite ${ }^{3 \pm=(0)}$
}

${ }^{1}$ Programa de Pós-Graduação em Ciência e Tecnologia para Recursos Amazônicos, Universidade Federal do Amazonas (UFAM), Itacoatiara, AM, Brazil. ${ }^{2}$ Universidade Federal do Amazonas (UFAM), Itacoatiara, AM, Brazil. ${ }^{3}$ Programa de Pós-Graduação em Zoologia, Universidade Federal de Mato Grosso (UFMT), Cuiabá, MT, Brazil.

表牛Corresponding author: peterson_demite@yahoo.com.br

Edited by: Nikolas G. Cipola

Received: October 01, 2021. Accepted: November 19, 2021. Published: December 23, 2021.

Abstract. Phytoseiid mites collected on Inga edulis L. (Leguminosae) in three localities in the Amazonas State, Brazil, were identified as Neoparaphytoseius charapa Jiménez, McMurtry \& Moraes, 2014. This is the first report of this species in Brazil. Notes on geographic occurrence and association of Neoparaphytoseius Chant \& McMurtry, 2003 species with host plants are presented.

Keywords: Amazon Forest, diversity, Mesostigmata, Parasitiformes, predatory.

Phytoseiid mites are the most studied and successfully used predators in the biological control of pest mites as well as of small insects, especially of thrips and whiteflies (McMurtry et al. 2013). To date, more than 2,800 species in this family have been described, in almost 100 known genera (Demite et al. 2021). The genus Neoparaphytoseius Chant \& McMurtry, 2003 has three known species, all registered in South America: Neoparaphytoseius sooretamus (El-Banhawy, 1984) and N. caatinga Silva, Silva \& Moraes, 2021, both recorded in Brazil, and N. charapa Jiménez, McMurtry \& Moraes, 2014, registered, so far, only in Peru. This study aimed to report the phytoseiid $N$. charapa for the first time in Brazil.

Leaf samples of many plant species including Inga edulis Mart. (Leguminosae) were collected in the field and taken to a laboratory for examination under a dissecting microscope. The phytoseiid specimens found were mounted on microscope slides in Hoyer's medium. After dried, they were examined under a phase-contrast microscope (Zeiss Axio Imager M3). Identification to genus level was done mostly based on Chant \& McMurtry (2007). Later, the species identification was based on a key presented in Silva et al. (2021) and comparing with the morphological information provided in the original description of species. Measurements of taxonomically relevant structures were done with the use of a graded eyepiece.

The distribution map of Neoparaphytoseius species was created using Simplemappr (Shorthouse 2010) based on data obtained from literature and made available by some authors when these were not in the publications. Voucher specimens were deposited at the Acari Collection of Departamento de Ciências Biológicas, UNESPUniversidade Estadual Paulista, São José do Rio Preto, São Paulo, Brazil: Manaus (02 $39^{\prime}$ S; 6003'W), 21 June 2019, A.C.C. Cavalcante collector (four females); 14 November 2019, R.B. Souza coll. (one female); Itacoatiara $\left(03^{\circ} 06^{\prime} \mathrm{S} ; 58^{\circ} 33^{\prime} \mathrm{W}\right), 12$ July 2019, M.P. Duque and S.A. Amorim coll. (one female); Silves (02 $57^{\prime} \mathrm{S}$; $58^{\circ} 29^{\prime} \mathrm{W}$ ), 16 December 2019, R.B. Souza coll. (four females); 06 March 2020 (one female and one male). All specimens were collected on I. edulis.

The phytoseiid identified was Neoparaphytoseius charapa (Fig. 1), described from Peru, associated with I. edulis leaves (Jiménez et al.
2014). The measurements recorded in the Brazilian specimens (females and a male) are very close to those reported in the original description (Tab. 1). A variation in the insertion of the $R 1$ setae was observed. In most specimens, the setal pair $R 1$ was located off the dorsal shield, in accordance with the original description. However, in one specimen, one of the setae of this pair was on the dorsal shield, and in another specimen, the two setae of this pair were on the dorsal shield.

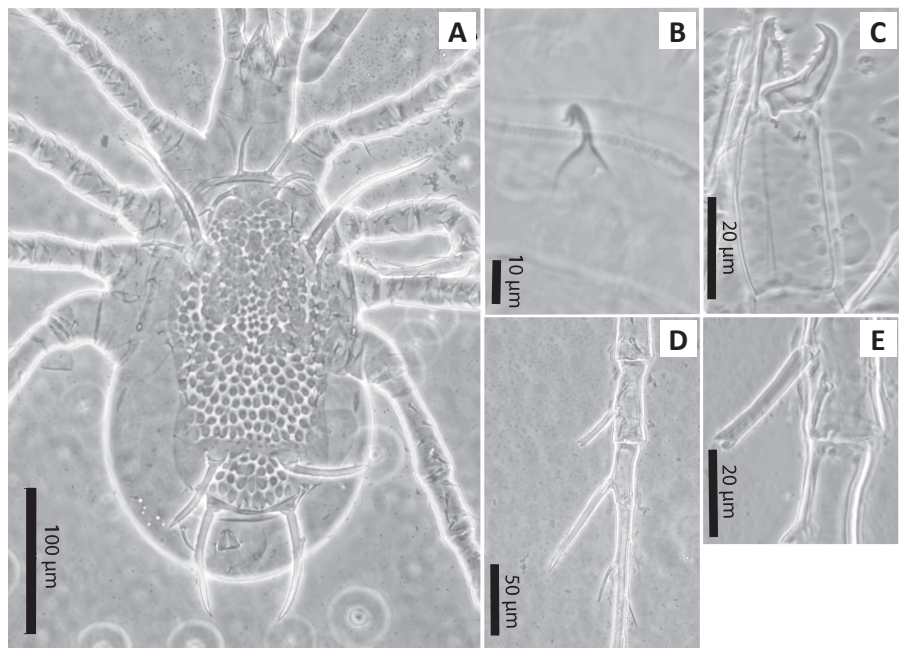

Figure 1. Neoparaphytoseius charapa Jiménez, McMurtry \& Moraes, 2014: (A) Dorsal view; (B) Spermatheca; (C) Chelicera; (D) Femur, genu, tibia and tarsus (part) of leg IV; (E) Macroseta of the tibia of leg IV.

As in the original description, all specimens were collected in association with $I$. edulis leaves. Inga edulis is a plant native to the Amazon that has pubescent leaves (with trichomes) and extrafloral nectaries on the petioles. The other two species of the genus have also been reported in plants with leaves with trichomes. Neoparaphytoseius sooretamus has already been reported on species of Malpighiaceae (Byrsonima intermedia A. Juss.: Rezende \& Lofego 2011), Myrtaceae (Eugenia stipitata McVaugh: Vasconcelos \& Silva 2015), Rosaceae 
Table 1. Measures of the original description of Neoparaphytoseius charapa Jiménez, McMurtry \& Moraes, 2014 and measures of specimens collected in Amazonas state, Brazil.

\begin{tabular}{|c|c|c|c|c|c|}
\hline \multirow{3}{*}{ Character } & \multicolumn{2}{|c|}{ Female } & \multicolumn{3}{|c|}{ Male } \\
\hline & Jiménez et al. (2014) & This study & & énez et al. (2014) & This study \\
\hline & Peru $(n=3)$ & Brazil $(n=10)$ & Character & Peru $(n=1)$ & Brazil $(n=1)$ \\
\hline DSL & $336(331-343)$ & $329(320-340)$ & DSL & 257 & 265 \\
\hline DSW & $175(167-182)$ & $172(165-180)$ & DSW & 134 & 130 \\
\hline j1 & $51(47-55)$ & $53(50-57)$ & j1 & 42 & 41 \\
\hline$j 3$ & $44(35-50)$ & $41(35-47)$ & j3 & 39 & 33 \\
\hline j4 & 5 & $5(5-7)$ & $j 4$ & 5 & 6 \\
\hline j5 & 5 & $5(5-7)$ & j5 & 5 & 5 \\
\hline$j 6$ & 5 & $5(5-6)$ & $j 6$ & 5 & 5 \\
\hline$J 2$ & 5 & $6(5-7)$ & $J 2$ & 5 & 6 \\
\hline$J 5$ & 5 & $5(5-6)$ & $J 5$ & 5 & 6 \\
\hline$z 2$ & $17(15-18)$ & $20(16-22)$ & $z 2$ & 14 & 16 \\
\hline 24 & $7(6-8)$ & $8(6-11)$ & $z 4$ & 8 & 8 \\
\hline 25 & 5 & $6(5-7)$ & 25 & 5 & 6 \\
\hline$Z 1$ & 8 & $10(9-11)$ & $Z 1$ & 6 & 8 \\
\hline$Z 4$ & $81(75-85)$ & $83(77-86)$ & $Z 4$ & 50 & 49 \\
\hline$Z 5$ & 107 (98-115) & $111(104-120)$ & $Z 5$ & 70 & 0,63 \\
\hline$s 4$ & $145(122-158)$ & $145(135-152)$ & $s 4$ & 109 & 105 \\
\hline$S 2$ & $17(15-18)$ & $19(17-21)$ & $S 2$ & 10 & 12 \\
\hline S5 & $26(20-30)$ & $27(26-31)$ & S5 & 15 & 14 \\
\hline$r 3$ & 35 (35-36) & $39(36-43)$ & $r 3$ & 25 & 27 \\
\hline R1 & $14(13-15)$ & $15(13-16)$ & R1 & 10 & 12 \\
\hline st1-st3 & $64(62-67)$ & $66(62-69)$ & st1-st3 & & \\
\hline st2-st2 & $69(68-70)$ & 71 (67-74) & st2-st2 & & \\
\hline st5-st5 & 85 (78-90) & $74(70-80)$ & st5-st5 & & \\
\hline VSL & $108(105-110)$ & $119(108-130)$ & VSL & 103 & 101 \\
\hline VSWant & $82(80-84)$ & $81(75-88)$ & VSWant & 172 & 170 \\
\hline VSWpost & & $73(69-80)$ & VSWpost & & 75 \\
\hline JV5 & & $35(32-42)$ & JV5 & & 17 \\
\hline calyxL & $10(10-11)$ & $10(9-11)$ & sprmtdL & 18 & 19 \\
\hline FDL & $30(30-31)$ & $30(28-31)$ & FDL & 21 & 23 \\
\hline FDteeth & 11 & 9 to 11 & FDteeh & 7 & 8 \\
\hline MDL & $27(26-28)$ & $30(29-31)$ & MDL & 20 & 20 \\
\hline MDteeth & 3 & 3 & MDteeth & 1 & 1 \\
\hline StilV & $39(37-40)$ & $40(36-43)$ & StilV & 27 & 30 \\
\hline StIV & $82(78-85)$ & $88(80-96)$ & StIV & 61 & 68 \\
\hline
\end{tabular}

DSL: Dorsal shield length; DSW: Dorsal shield width; VSL: Ventrianal shield length; VSWant: Ventrianal shield width at level JV2; VSWpost: Ventrianal shield width at level anus; calyxL: calyx of spermatheca length; sprmtdL: shaft of spermatodactyl length; FDL: Fixed digit length; MDL: Movable digit length.

(Rubus brasiliensis Mart. and R. urticifolius Poir: Moraes et al. 2013), and Solanaceae (Solanum grandiflorum Ruiz \& Pav., S. paniculatum L., S. stramonifolium Jacq. and Solanum sp.: Rosa et al. 2005; Fiaboe et al. 2007); $N$. caatinga has been reported on Euphorbiaceae (Croton blanchetianus Baill.: Silva et al. 2021). Mites of the genus Neoparaphytoseius probably fit the classification of McMurtry et al. (2013) as subtype-Illa, which includes generalists associated with pubescent leaves. Species of the genera Kampimodromus Nesbitt, 1951 and Paraphytoseius Swirski \& Schechter, 1961, which belong to the same tribe (Kampimodromini), are also classified in this subtype. Species of this subtype have the idiosoma typically small and laterally compressed that apparently aids them in moving between leaf trichomes (Duso 1992; Walter 1992; Karban et al. 1995; Kreiter et al. 2002; 2003; Tixier et al. 2007). According to McMurtry et al. (2013), these phytoseiids are characterized by having some dorsal setae thick and usually serrated. These morphological characteristics allow these mites to colonize microhabitats not occupied by large phytoseiids, preventing competition and escaping predation by these latter mites (Seelmann et al. 2007), and allowing them to take advantage of the presence of prey that prefers the same habitat.

Neoparaphytoseius charapa is now recorded in Brazil and Peru (Fig. 2). In both countries, this species was registered in the Amazon Forest biome. On the other hand, N. sooretamus was recorded in several locations in Brazil, from the state of São Paulo to the state of Amazonas, in areas of Cerrado (Rezende \& Lofego 2011), Amazon Forest (Vasconcelos \& Silva 2015) and Atlantic Forest (El-Banhawy 1984; Zacarias \& Moraes 2001; Furtado et al. 2005; Rosa et al. 2005; Fiaboe et al. 2007; Castro \& Moraes 2010; Moraes et al. 2013). 
Neoparaphytoseius caatinga, a recently described species, was recorded in an area of the Caatinga biome, in the state of Alagoas (Silva et al. 2021).

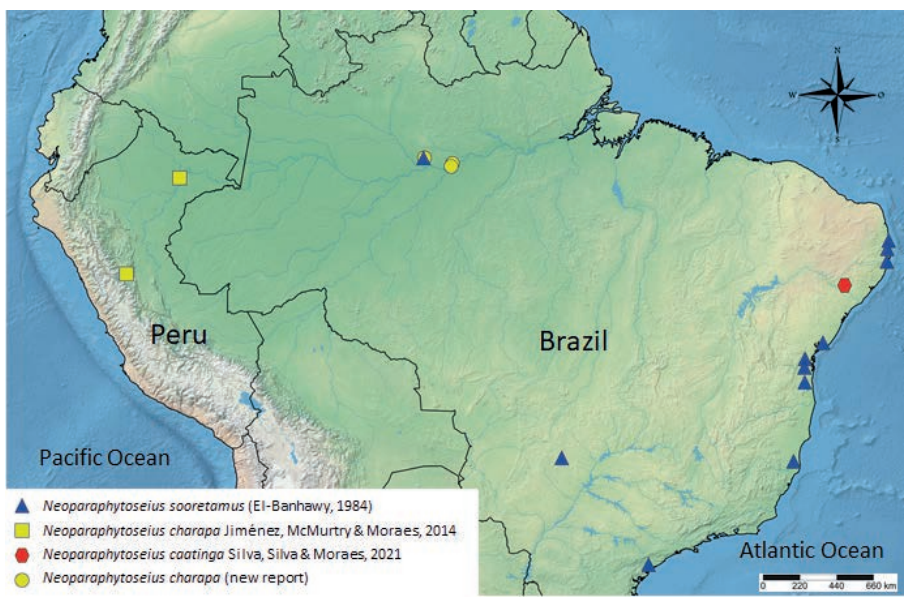

Figure 2. Geographical distribution of species of Neoparaphytoseius Chant \& McMurtry, 2003. Source: Neoparaphytoseius caatinga Silva, Silva \& Moraes, 2021 - Silva et al. (2021); Neoparaphytoseius charapa Jiménez, McMurtry \& Moraes, 2014 - Jiménez et al. (2014); Neoparaphytoseius sooretamus (ElBanhawy, 1984) - El-Banhawy (1984), Zacarias \& Moraes (2001), Furtado et al. (2005), Rosa et al. (2005), Fiaboe et al. (2007), Castro \& Moraes (2010), Rezende \& Lofego (2011), Moraes et al. (2013) and Vasconcelos \& Silva (2015).

\section{Acknowledgments}

To Antonio C. Lofego (UNESP, S.J. do Rio Preto, São Paulo) by making available phase-contrast microscopy of Laboratório de Acarologia, UNESP S.J. do Rio Preto, for measurements and photographies of this species. RBS reveibed a scholarship from "Coordenação de Aperfeiçoamento de Pessoal de Nível Superior" (CAPES) - Finance Code 001; MPD receibed schorlarship from "Conselho Nacional de Pesquisa e Desenvolvimento Tecnológico" (CNPq); SAA receibed schorlarship from "Fundação de Amparo à Pesquisa do Estado do Amazonas" (FAPEAM); PRD receives a schorlarship (PNPD) from the "Coordenação de Aperfeiçoamento de Pessoal de Nível Superior" (CAPES) (Proc 88887.373867/2019-00). To Manoel G.C. Gondim Jr. (UFRPE, Recife) and Geraldo J. N. de Vasconcelos (UFAM, Itacoatiara) for the information on the hosts of $N$. sooretamus registered in Pernambuco and Amazonas, respectively.

\section{Authors' Contributions}

RBS, MPD and SAA conducted the fieldwork. RBS, ACCC and PRD identified the mites. RBS, MPD, SAA, ACCC and IRG prepared the manuscript. All authors revised the final version of the manuscript.

\section{References}

Castro, T. M. M. G. de; Moraes, G. J. de (2010) Diversity of phytoseiid mites (Acari: Mesostigmata: Phytoseiidae) in the Atlantic Forest of São Paulo. Systematics and Biodiversity, 8(2): 301-307. doi: 10.1080/14772001003801375

Chant, D. A.; McMurtry, J. A. (2007) Illustrated Keys and diagnoses for the genera and subgenera of the Phytoseiidae of the world (Acari: Mesostigmata). West Bloomfield: Indira Publishing House.

Demite, P. R.; Moraes, G. J. de; McMurtry, J. A.; Denmark, H. A.; Castilho, R. C. (2021) Phytoseiidae Database. www.lea.esalq.usp. br/phytoseiidae. Access on: 19.ix.2021.

Duso, C. (1992) Role of Amblyseius aberrans (Oud.), Typhlodromus pyri (Scheuten) and Amblyseius andersoni (Chant) (Acari: Phytoseiidae) in vineyards. Journal of Applied Entomology, 114: 455-462. doi: 10.1111/j.1439-0418.1992.tb01151.x

El-Banhawy, E. M. (1984) Description of some phytoseiid mites from Brazil (Acarina: Phytoseiidae). Acarologia, 25(2): 125-144.

Fiaboe, K. K. M.; Gondim Jr., M. G. C.; Moraes, G. J. de; Ogol, C. K. P.
O.; Knapp, M. (2007) Surveys for natural enemies of the tomato red spider mite Tetranychus evansi (Acari: Tetranychidae) in northeastern and southeastern Brazil. Zootaxa, 1395: 33-58. doi: 10.11646/zootaxa.1395.1.2

Furtado, I. P.; Kreiter, S.; Moraes, G. J. de; Tixier, M.-S., Flechtmann, C. H. W.; Knapp, M. (2005) Plant mites (Acari) from Northeastern Brazil, with description of two new species of the family Phytoseiidae (Mesostigmata). Acarologia, 45(2-3): 131-143.

Jiménez, S.; McMurtry, J. A.; Moraes, G. J. de (2014) Description of a new species of Neoparaphytoseius Chant and McMurtry (Acari: Mesostigmata: Phytoseiidae) from Peru, with a redefinition of the genus. Zootaxa, 3841(2): 293-300. doi: 10.11646/zootaxa.3841.2.8 Karban, R.; Englishloeb; G., Walter, M. A.; Thaler, J. (1995) Abundance of phytoseiid mites on Vitis species: effects of leaf hairs, domatia, prey abundance and plant phylogeny. Experimental and Applied Acarology, 19: 189-197. doi: 10.1007/BF00130822

Kreiter, S.; Tixier, M.-S.; Bourgeois, T. (2003) Do generalist phytoseiid mites (Gamasida: Phytoseiidae) have interactions with host plants? Insect Science \& its Application, 23: 35-50.

Kreiter, S.; Tixier, M.-S.; Croft, B. A.; Auger, P.; Barret, D. (2002) Plant and leaf characteristics influencing the predaceous mite Kampimodromus aberrans (Acari: Phytoseiidae) in habitats surrounding vineyards. Environmental Entomology, 31: 648-660. doi: 10.1603/0046-225X-31.4.648

McMurtry, J. A.; Moraes, G. J. de; Famah Sourassou, N. (2013) Revision of the lifestyles of phytoseiid mites (Acari: Phytoseiidae) and implications for biological control strategies. Systematic and Applied Acarology Society, 18(4): 297-320. doi: 10.11158/saa.18.4.1

Moraes, G. J. de; Barbosa, M. F. de C.; Castro, T. M. M. G. de (2013) Phytoseiidae (Acari: Mesostigmata) from natural ecosystems in the State of São Paulo, Brazil. Zootaxa, 3700(3): 301-347. doi: 10.11646/zootaxa.3700.3.1

Rezende, J. M.; Lofego, A. C. (2011) Phytoseiidae (Acari: Mesostigmata) on plants of the central region of the Brazilian Cerrado. Acarologia, 51(4): 449-463. doi: 10.1051/acarologia/20112027

Rosa, A. S.; Gondim Jr., M. G. C.; Fiaboe, K. K. M.; Moraes, G. J. de; Knapp, M. (2005) Predatory mites associated with Tetranychus evansi Baker \& Pritchard (Acari: Tetranychidae) on native solanaceous plants of coastal Pernambuco State, Brazil. Neotropical Entomology, 34(4): 689-692. doi: 10.1590/S1519-566X2005000400021

Seelmann, L.; Auer, A.; Hoffmann, D.; Schausberger, P. (2007) Leaf pubescence mediates intraguild predation between predatory mites. Oikos, 116: 807-817. doi: 10.1111/j.0030-1299.2007.15895.x

Shorthouse, D. P. (2010) SimpleMappr, an online tool to produce publication-quality point maps. www.simplemappr.net. Access on: 20.ix.2021.

Silva, L. R. A.; Silva, E. S.; Marticorena, J. L. M.; Moraes, G. J. de (2021) A new species of Neoparaphytoseius (Acari: Mesostigmata: Phytoseiidae) from Brazil, with a review of the genus. Zootaxa, 4985(2): 235-244. doi: 10.11646/zootaxa.4985.2.6

Tixier, M.-S.; Kreiter, S.; Bourgeois, T.; Cheval, B. (2007) Factors affecting density and diversity of phytoseiid mite communities in two arboreta in the South of France. Journal of Egyptian Society of Parasitology, 37: 493-510.

Vasconcelos, G. J. N. de; Silva, N. M. da (2015) Plant-inhabiting mites (Arachnida: Acari) in Amazonian agroecosystems. In: Sant'Anna, B. S.; Takeara, R.; Abegg, M. A. (Eds), Amazonian Resources: microbiota, fauna, and flora, pp. 99-113. New York: Nova Science Publishers.

Walter, D. E. (1992) Leaf surface structure and the distribution of Phytoseius mites (Acarina: Phytoseiidae) in South-eastern Australian forest. Australian Journal of Zoology, 40(6): 593-603. doi: 10.1071/ZO9920593

Zacarias, M. S.; Moraes, G. J. de (2001) Phytoseiid mites (Acari) associated with rubber trees and other euphorbiaceous plants in southeastern Brazil. Neotropical Entomology, 30(4): 579-586. doi: 10.1590/S1519-566X2001000400011 